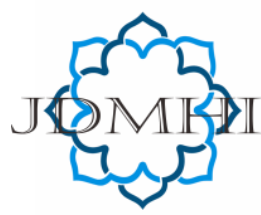

email: jdmhi@walisongo.ac.id

Journal of Digital Marketing and Halal Industry

ISSN: 2716-4810 (print) ISSN: 2716-4802 (online)

\title{
The Effect of the Application of Total Quality Management, Supply Chain Management, and Entrepreneurship Orientation on Operational Performance
}

\section{Siti Nur Latifah, Wijayanti, Esti Magiyanti Utami}

Universitas Muhammadiyah Purworejo, Indonesia

\section{A R T I C LE I N F O}

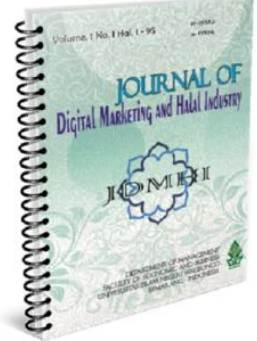

Article history:

Received 29 January 2021

Accepted 22 April 2021

Published 30 April 2021

Keywords:

Total Quality Management,

Supply Chain Management,

Entrepreneurial Orientation,

Operating Performance.
A B S T R A C T

Small and medium enterprises in the food sector in the pandemic era were significantly affected, so SMEs need to improve their performance, so they are not significantly affected. This study aims to examine the effect of implementing TQM on the operational performance of Food SMEs, examining the effect of SCM application on the operational performance of Food SMEs, and examining the effect of the application of entrepreneurial orientation on the operational performance of Food SMEs in Wonosobo Regency. This study used a purposive sampling technique and obtained a total sample of 120 people. This study used a survey research design and data collection was carried out using a questionnaire. Data analysis was performed using multiple linear regression. The results of multiple linear regression and hypothesis testing show that the TQM variable has a positive and significant effect on operating performance. The SCM variable has a positive and significant effect on operating performance. The entrepreneurial orientation variable has a positive and significant effect on operating performance.

@2021 Journal of Digital Marketing and Halal Industry

\section{Introduction}

The world is currently developing rapidly, especially in industry or business. This has an impact on increasing competition between existing industries or businesses. Various attempts were made to become the best industry or business (Rusdiana, 2014). The central problem facing an industry or business today is how to create the best strategy to survive and develop. This goal will be achieved if the industry or business carries out the production process correctly (Rusdiana, 2014). According to (Yamit, 2003) the production process is the process of changing (transformation) from a material or component (input) to another product that

* Corresponding author.email:wijayanti@umpwr.ac.id DOI: http://dx.doi.org/10.21580/jdmhi.2021.3.1.7441 
has a higher value or in the process of adding value (output).

Operations management has a major role in the production process of a company, and the performance generated by operations management is very important for the sustainability of the company (Heizer \& Render, 2015). According to the Head of the Department of Trade, Cooperatives, Small and Medium Enterprises of Wonosobo Regency in the field of MSMEs Cooperatives Nugrahadi, S.E, M.M, Wonosobo has 60,000 MSMEs spread across 15 Districts. However, efforts to improve class are still quite difficult because they are hindered by the mindset of actors, bad business management, and a lack of budget. Business actors are required to be creative and innovative in business operational management. According to (Moeheriono, 2014) operation performance is a performance related to the effectiveness of the use of every resource used by a company such as capital, raw materials, technology, and others.

According to (Modgil \& Sharma, 2016) operational performance is influenced by Total Quality Management (TQM) because TQM is a management philosophy and manufacturing strategy that aims to improve and maintain the quality of products and processes continuously. According to (Tatoglu, Glaister, \& Demirbag, 2015) operational performance is influenced by Supply Chain Management (SCM). SCM or supply chain management describes the coordination of the entire supply chain activities, starting with raw materials and ending with satisfied customers (Heizer \& Render, 2015). According to (Rauch, Wiklund, Lumpkin, \& Frese, 2009) operating performance in a business is influenced by entrepreneurial orientation, because entrepreneurial orientation can be seen as a process of making entrepreneurial strategies that are used as the main decision making to set organizational goals, implement the vision or goals, and creating innovations to achieve a competitive advantage.

One group of local producers who feel the impact of competition involving ordering raw materials, a series of production processes, quality checking, to delivery and entrepreneurial orientation carried out by business actors is the Food Small and Medium Enterprises (UKM) in Wonosobo Regency. According to data from the Department of Trade, Cooperatives, Small and Medium Enterprises of Wonosobo Regency (2019), the number of Food SMEs in Wonosobo Regency is increasing every year. Based on the various problems that have been described, it can be concluded that most of the problems that occur are in the scope of operating performance. This study aims to examine the effect of implementing TQM on the operational performance of Food SMEs, examining the effect of SCM application on the operational performance of Food SMEs, and examining the effect of the application of entrepreneurial orientation on the operational performance of Food SMEs in Wonosobo Regency.

\section{Literature Review}

Micro, Small, and Medium Enterprises are a form of small-scale economic activity of the people and meets the criteria for net assets or annual sales proceeds and ownership as regulated by law. According to Law Number 20 of 2008 concerning Micro, Small, and 
Medium Enterprises are productive economic enterprises that are independent and carried out by individuals or business entities that are not subsidiaries that are owned, controlled, or are part of either directly or indirectly from medium-sized enterprises. or big effort. The classification of Small and Micro Enterprises according to the Central Statistics Agency refers to the number of workers in the business (Dhewanto, 2015).

1. A micro business has less than 5 workers, including additional unpaid family members.

2. A small business is a business that has 5 to 19 workers.

3. Medium-sized enterprises are businesses that have 19 to 99 workers.

According to (Sumarsono: 2003) several reasons support the importance of developing micro and small industries, including:

1. It's potential for creating and expanding the workforce for the unemployed

2. To increase the income of the surrounding community

3. To realize the skills (skills) possessed by the community.

Such is the importance of the Micro and Small Industries for the Indonesian economy. Industrial Operation Performance needs to be considered.

According to (Moeheriono, 2014) operation performance is a performance related to the effectiveness of the use of every resource used by a company such as capital, raw materials, technology, and others. Total Quality Management (TQM) According to (Tjiptono \& Diana, 2003) Total Quality Management (TQM) is an approach in running a business that tries to maximize organizational competitiveness through continuous improvement of products, services, people, processes, and the environment. Supply Chain Management (SCM) describes the coordination of the entire supply chain activities, starting with raw materials and ending with satisfied customers (Heizer \& Render, 2015). According to (Darmanto, Wardaya, \& Sulistyani, 2018) entrepreneurship orientation is a strategy that focuses on actions that lead to the implementation of entrepreneurship, namely the process of identifying, developing, and carrying a vision.

\section{Hypothesis Development}

Modgil \& Sharma, (2016) explain that TQM influences operating performance because TQM is a management philosophy and manufacturing strategy that aims to improve and maintain the quality of products and processes continuously. TQM has been considered the most important approach to achieving competitive advantage. This is because TQM helps top management to make strategic decisions. Meanwhile, according to (Kaynak, 1997) that the relationship between TQM and company performance that shows a positive effect is examined by using theories of the relationship between innovation, strategy, and performance. Various studies have shown that TQM practices affect operating performance. Research conducted by (Labdhagati \& Mahfudz, 2017), (Dhaafri \& Swidi, 2016), (Baird, Hu, \& Reeve, 2011), (Modgil \& Sharma, 2016) concluded that TQM has a positive effect on operating performance.

H1: TQM has a positive effect on operating performance.

Effect of SCM on Operational Performance 
In SCM there is a vertical integration model (vertical integration) which provides substantial opportunities for cost reduction, higher quality, on-time delivery, and reduced supplies (Heizer and Render, 2015: 503). SCM as systemic, strategic coordination of traditional business functions, and tactics across business functions within a particular company and throughout the business in the supply chain to improve the long-term performance of each company and for the entire supply chain (Mentzer et al., 2001). According to (Tatoglu et al., 2015) SCM influences operating performance. SCM consists of specific approaches and practices to effectively integrate suppliers, manufacturers, distributors, and customers to improve the sustainable performance of individuals and supply chains in a cohesive business model. Various studies have shown that SCM practices affect operating performance. Research conducted by (Labdhagati \& Mahfudz, 2017), (Fitrianto \& Sudaryanto, 2016), (Devaraj, Krajewski, \& Wei, 2007), (Li, Ragu-nathan, Ragu-nathan, \& Rao, 2006), (Tatoglu et al., 2015) concluded that SCM has a positive effect on operating performance.

H2: SCM has a positive effect on operating performance.

According to Foltean (2007) (Darmanto, Wardaya, \& Dwiyani, 2019), entrepreneurial orientation strategies and entrepreneurial behavior which include proactiveness, innovation, risk-taking, autonomy, and competitive aggressiveness can improve organizational performance for companies operating in a dynamic environment. (Lumpkin \& Dess, 1996) explaining the relationship between entrepreneurial orientation and performance through the role of environmental and organizational variables shows that entrepreneurial orientation contributes to optimal performance (Lumpkin \& Dess, 1996). According to (Rauch et al., 2009) entrepreneurial orientation influences operating performance, because entrepreneurial orientation can be seen as a process of making entrepreneurial strategies that are used as the main decision making to set organizational goals, implement vision or goals, and create innovations to achieve competitive advantage. . Various studies have shown that attitudes in entrepreneurial orientation can affect operating performance. Research conducted by (Labdhagati \& Mahfudz, 2017), (Dhaafri \& Swidi, 2016), (Zhang \& Zhang, 2012) and (Rauch et al., 2009).

H3: Entrepreneurial orientation has a positive effect on operating performance.

\section{The Method, data, and analysis}

This research is included in quantitative research because the data obtained is in the form of numbers derived from questionnaires. This study used a survey method by taking a sample from the population using a questionnaire as a data collection tool (Sugiyono, 2015). The sampling method in this study used nonprobability sampling in the form of purposive sampling technique (judgment sampling), which is a sampling technique carried out by taking samples from the population-based on certain criteria (Ghozali, 2018). The criteria are defined as follows. 1 . Food SMEs that have been registered with the Department of Trade, Cooperatives and 
Small and Medium Enterprises of Wonosobo Regency 2. SMEs that have been in business for more than one year 3. UKM has a minimum of 5 employees 4 . SMEs implement an inventory system Based on the criteria specified above, a sample of 120 Food UKM players in Wonosobo Regency was obtained as research respondents.

\section{Operational Definition Variables}

Total Quality Management (TQM) TQM is an approach in running a business that tries to maximize organizational competitiveness through continuous improvement of products, services, people, processes, and their environment (Tjiptono \& Diana, 2003) Goetsch and Davis in (Tjiptono \& Diana, 2003) suggest indicators TQM includes: 1) Focus on the customer 2) Obsession with quality 3) Scientific approach 4) Long term commitment 5) Teamwork (teamwork) 6) Continuous system improvement 7) Freedom of control 8) Unity of purpose 9) There is employee involvement and empowerment Supply Chain Management (SCM) SCM or supply chain management describes the coordination of the entire supply chain activities, starting with raw materials and ending with satisfied customers (Heizer \& Render, 2015). suggested that SCM indicators include: 1) Relationship with suppliers (supplier partnership) 2) Customer relationship 3) The level of information sharing (information sharing) 4) Quality of information sharing Entrepreneurial Orientation According to (Darmanto et al., 2018) entrepreneurship orientation is a strategy that focuses on actions that lead to the implementation of entrepreneurship, namely the process of identifying, developing and carrying a vision. (Darmanto et al., 2019) suggest entrepreneurial orientation indicators include: 1) Proactiveness 2) Innovation 3) Risk-taking 4) Autonomy 5) Competitive aggressiveness Operating Performance According to (Moeheriono, 2014) operation performance is a performance related to the effectiveness of the use of every resource used by a company such as capital, raw materials, technology, and others. The following are some operating performance indicators (Devaraj et al., 2007), (Zhang \& Zhang, 2012), (Modgil \& Sharma, 2016) including 1) Percentage of products returned by customers (returns) 2) Percentage of defective products during production 3) Speed of delivery 4) Reliability of delivery 5) Procurement of supplies 6) The effectiveness of production costs 7) Production lead time 8) Process flexibility

\section{Result and Discussion}

This research was conducted on 120 Food SMEs in Wonosobo Regency to determine the effect of Total Quality Management (TQM), Supply Chain Management (SCM), and Entrepreneurship Orientation on Operational Performance. Following are the results of the Multiple Linear Regression analysis.

Table 1. Multiple Linear Regression Test Results

\begin{tabular}{cccc}
\hline Variable & $\begin{array}{c}\text { Standardized } \\
\text { Coefficients Beta }\end{array}$ & $\begin{array}{c}\text { p-value } \\
(\text { sig. })\end{array}$ & Information \\
\hline TQM (X1) & 0,640 & 0,000 & $\begin{array}{c}\text { Positive and } \\
\text { significant }\end{array}$ \\
SCM (X2) & 0,142 & 0,040 & $\begin{array}{c}\text { Positive and } \\
\text { significant }\end{array}$ \\
EO (X3) & 0,160 & 0,021 & $\begin{array}{c}\text { Positive and } \\
\text { significant }\end{array}$ \\
\hline
\end{tabular}

Source: Primary Data Processed, 2020

Based on table 1, the multiple linear 
regression equation models that can be written from the results of this study are:

$\mathrm{Y}=0.640+0.142+0.160$

With the following interpretation:

$\mathrm{b}=0.640$ is positive, meaning that TQM (X1)

has a positive effect on operating performance.

$\mathrm{b}=0.142$ is positive, meaning that SCM (X2)

positive effect on operating performance.

$\mathrm{b}=0.160$ is positive, meaning that $\mathrm{EO}(\mathrm{X} 3)$

has a positive effect on operating performance.

\section{Partial Significance Test Results}

Based on table 1, the results of the partial significance test can be explained as follows:

The p-value of TQM (X1) is $0.000(<0.05)$. This shows that TQM has a significant effect on operating performance $(\mathrm{Y})$.

The p-value of SCM (X2) is $0.040(<0.05)$. This shows that SCM has a significant effect on operating performance (Y).

The $\mathrm{p}$-value of entrepreneurial orientation (X1) is $0.021 \quad(<0.05)$. This shows that entrepreneurial orientation has a significant effect on operating performance $(\mathrm{Y})$.

\section{Discussion}

TQM has a positive and significant effect on operating performance

Based on the results of multiple linear regression analysis in table 1 , it can be seen that TQM has a positive effect on the operating performance of 0.640 with a significant value of $0.000(<0.05)$. This shows that the first hypothesis $(\mathrm{H} 1)$ is accepted. The operating performance of Food SMEs is influenced by TQM in terms of improving and maintaining the quality of their products and processes. Food SMEs improve the quality of their processes and products so that they can compete with other business actors and achieve their business goals. To produce the best quality, this is done through continuous improvement of the capabilities of its human resources, processes, and business environment. Business actors who focus on their customers have a long-term commitment to their performance, can work together and empower their employees to be able to produce good and optimal operating performance in running a business.

The results of this study are following the theory (Modgil \& Sharma, 2016) and (Kaynak, 1997) regarding the operational performance of the manufacturing process that needs to apply TQM. Where TQM is a management philosophy and manufacturing strategy that aims to improve and maintain the quality of products and processes on an ongoing basis. This continuous improvement is the result of top management commitment and workforce involvement which causes the organization to exceed customer expectations. TQM is considered the most important approach to competitive advantage because TQM helps top management to make strategic decisions (Modgil \& Sharma, 2016). The results of this study support previous research conducted by (Labdhagati \& Mahfudz, 2017), (Dhaafri \& Swidi, 2016), (Baird et al., 2011), and (Modgil \& Sharma, 2016) which concluded that TQM has a positive effect on operating performance.

\section{SCM has a positive and significant effect on operating performance}

Based on the results of multiple linear regression analysis in table 1 , it can be seen that SCM has a positive effect on the 
operating performance of 0.142 with a significant value of $0.040(<0.05)$. This shows that the second hypothesis ( $\mathrm{H} 2)$ is accepted. The operating performance of Food SMEs is influenced by SCM in terms of increasing integration of suppliers and customers in the supply chain. Business actors in carrying out operational activities such as designing products, obtaining raw materials, planning production and supplies to distributing products consider it important to implement SCM. Business actors that increase integration with suppliers and customers can increase operational effectiveness because they have succeeded in fulfilling production needs and customer demands more quickly and optimally. This of course also has an impact on the effectiveness of production and inventory costs and increases the ability to compete in businesses.

The results of this study are following the theory (Tatoglu et al., 2015) which states that SCM affects operating performance. Where SCM consists of specific approaches and practices to effectively integrate suppliers, manufacturers, distributors, and customers to improve the sustainable performance of individuals and supply chains in a cohesive business model. The results of this study support previous research conducted by (Labdhagati \& Mahfudz, 2017), (Fitrianto \& Sudaryanto, 2016), (Devaraj et al., 2007), (Li et al., 2006) (Tatoglu et al., 2015) who concluded that SCM has a positive effect on operating performance.

\section{Conclusion}

Based on the results of research and discussion of the effect of the application of TQM, SCM, and entrepreneurial orientation on the operational performance of the Food
SMEs in Wonosobo Regency, it can be concluded that TQM has a positive and significant effect on operating performance. This shows that the operating performance of Food SMEs is affected by TQM in terms of improving and maintaining the quality of their products and processes. The results of this study support previous research conducted by (Labdhagati \& Mahfudz, 2017), (Dhaafri \& Swidi, 2016), (Baird et al., 2011), and (Modgil \& Sharma, 2016) which concluded that TQM has a positive effect on operating performance. SCM has a positive and significant effect on operating performance. This shows that the operating performance of Food SMEs is influenced by SCM in terms of increasing supplier and customer integration in the supply chain. The results of this study support previous research conducted by (Labdhagati \& Mahfudz, 2017), (Fitrianto \& Sudaryanto, 2016), (Devaraj et al., 2007), (Li et al., 2006) (Tatoglu et al., 2015) who concluded that SCM has a positive effect on operating performance. Entrepreneurial orientation has a positive and significant effect on operating performance. The operational performance of Food SMEs is influenced by entrepreneurial orientation in terms of increasing innovation and the courage to take opportunities and risks in their business. The results of this study support previous research conducted by (Labdhagati \& Mahfudz, 2017), (Dhaafri \& Swidi, 2016), (Zhang \& Zhang, 2012) and (Rauch et al., 2009) which concluded that entrepreneurial orientation has a positive effect on performance. operation.

\section{Recommendations}

This research is limited to food SMEs in Wonosobo Regency. Further research can be 
carried out by adding SMEs in other sectors and expanding the research area to generalize the research results.

\section{References}

Baird, K., Hu, K. J., \& Reeve, R. (2011). The relationships between organizational culture, total quality management practices and operational performance practices, and operational performance Department of Accounting and Finance Acknowledgments : We would like to thank Hale Kaynak for her assistance in carrying out this project. (August 2018). https://doi.org/10.1108/01443571111 144850

Darmanto, Wardaya, S., \& Dwiyani, T. (2019). Bauran Orientasi Strategi dan Kinerja Organisasi: Penerapan Variabel Anteseden, Moderasi, dan Mediasi dalam Penelitian Ilmiah. Yogyakarta: CV Budi Utama.

Darmanto, Wardaya, S., \& Sulistyani, L. (2018). Kiat Percepat Kinerja UMKM dengan Model Strategi Orientasi Berbasis Lingkungan. Yogyakarta: CV Budi Utama.

Devaraj, S., Krajewski, L., \& Wei, J. C. (2007). Impact of eBusiness technologies on operational performance: The role of production information integration in the supply chain. 25, 1199-1216. https://doi.org/10.1016/j.jom.2007.01. 002

Dhaafri, H. S. Al, \& Swidi, A. Al. (2016). The impact of Total Quality Management and Entrepreneurial Orientation on Organizational Performance.
International Journal of Quality $\mathcal{E}$ Reliability Management.

Dhewanto, W. (2015). Manajemen Inovasi untuk Usaha Kecil dan Mikro. Bandung: Alfabeta.

Fitrianto, A. Y., \& Sudaryanto, B. (2016). Pengaruh Supply Chain Management terhadap Kinerja Operasional Outlet (Studi Pada Counter Handphone yang terdaftar di PT. Multikom Indonesia Cabang Semarang). Diponegoro Journal of Management.

Ghozali, I. (2018). Aplikasi Analisis Multivariate dengan Program IBM SPSS 25. Semarang: BP UNDIP.

Heizer, J., \& Render, B. (2015). Operations Management: Sustainability and Supply Chain Managemen: Eleventh Edition. Jakarta: Salemba Empat.

Kaynak, H. (1997). Total Quality Management and Just in Time Purchasing. Journal of Operations Management.

Labdhagati, H., \& Mahfudz. (2017). Pengaruh Penerapan Total Quality Management, Supply Chain Management, dan Orientasi Kewirausahaan terhadap Kinerja Operasi (Studi pada Pengrajin Tas di Sentra Industri Tas Ciampea Kab. Bogor). Diponegoro Journal of Management.

Li, S., Ragu-nathan, B., Ragu-nathan, T. S., \& Rao, S. S. (2006). The impact of supply chain management practices on competitive advantage and organizational performance. The 
International Journal of Management Science, 34, 107-124. https://doi.org/10.1016/j.omega.2004. 08.002

Lumpkin, G., \& Dess, G. G. (1996). Clarifying the Entrepreneurial Orientation Construct and Linking It to Performance. Academy of Management Review, 21(1), 135-172.

Mentzer, J. T., Dewitt, W., Keebler, J. S., Min, S., Nix, N. W., Smith, C. D., \& Zacharia, Z. G. (2001). Defining Supply Chain Management. Journal of Business Logistics, 22(2), 1-25.

Modgil, S., \& Sharma, S. (2016). Total productive maintenance, total quality management and operational performance: An empirical study of Indian pharmaceutical industry. Journal of Quality in Maintenance Engineering. https://doi.org/10.1108/JQME-102015-0048

Moeheriono. (2014). Pengukuran Kinerja Berbasis Kompetensi (Edisi Revi). Jakarta: Raja Grafindo Persada.

Rauch, A., Wiklund, J., Lumpkin, G. T., \& Frese, M. (2009). Entrepreneurial Orientation and Business Performance: An Assessment of Past Research and Suggestions for The Future. Entrepreneurship Theory and Practice.

Rusdiana. (2014). Manajemen Operasi. Bandung: Pustaka Setia.

Sugiyono. (2015). Metode Penelitian Pendidikan: Pendekatan Kuantitatif, Kualitatif, dan REDD. Bandung: Alfabeta.

Tatoglu, E., Glaister, A. J., \& Demirbag, M. (2015). Talent Management MOtives and Practices in an Emerging Market: A Comparison Between MNEs and Local Firms. Journal of World Business.

Tjiptono, F., \& Diana, A. (2003). Total Quality Management. Yogyakarta: ANDI.

Yamit, Z. (2003). Manajemen Produksi dan Operasi. Yogyakarta: Ekonisia.

Zhang, Y., \& Zhang, X. (2012). The effect of entrepreneurial orientation on business performance: A role of network capabilities in China. Journal of Chinese Entrepreneurship. https://doi.org/10.1108/17561391211 242744 
